\title{
Development and growth of Islamic banking in Pakistan
}

\author{
Muhammad Ashraf \\ Superior University, Lahore, Pakistan. \\ Accepted 21st August, 2013
}

\begin{abstract}
This study analyzes the development and growth of Islamic banking in Pakistan. State banks of Pakistan are playing very important role in the development of Islamic banking and make Islamic banking as the first priority in the banking system. Islamic banking is providing a wide variety of the products which are competitive to the conventional banking system. Islamic banking generally shows an increasing trend in the total assets, total deposits, total financing, total investments, total number of branches, profits, earnings per shares, share holder equity and other financial indicators which shows the financial growth and development of the Islamic financial institutions. The study will help the higher management to make policies for the Islamic banking to grow and develop in low income or developing countries such as Pakistan.
\end{abstract}

Key words: Islamic banking, profit and loss sharing, development, growth, interest.

\section{INTRODUCTION}

Islamic banking system is a system which is established on the basis of the philosophy of Islamic laws (called Shariah) and directed by Islamic economics.

A new concept of Islamic banking emerged and has taken many observers as astonish. The purpose of Islamic banking emergence is to remove the interest (Riba) from all the transactions and to purify the financial system according to Shariah (Islamic Law). The prohibition of Interest (Riba) in the Holy Quran is the main factor in the emergence of Islamic banking. The Islamic banking is based on the profit and loss sharing (PLS) system in which the investor shares the risk and reward. Basically the main reason behind the set up of Islamic banking was the desire of Muslims community to make or organize their financial transactions according to the principles of Shariah (Islamic Law) and without any involvement of interest (Riba) accomplish their financial transactions. In fact, Shariah prohibits fixed return on investment and appreciates the investment in which the investor is rewarded in the terms of profit and loss sharing (PLS).

Shariah also prohibits the trading in which financial risk is involved because it is seen as a form of gambling.
Islamic banking main feature is interest free banking and Islamic banking is contributing more than this, such as unbiased distribution of income and wealth, and increased equity participation in economy. On the other hand, Islamic banking derives its specific rationale from the fact that interest free banking system has no place in the Islamic order.

However, Islamic banking is also important in the same sense as the Islamic law at the state level, as it mentioned in the Holy book (Quran) in four different revelations. The first revelation emphasizes that interest take away possessions, function or power of wealth of God's blessings. The second revelation condemns it, placing interest in juxtaposition with wrongful appropriation of property belonging to others. The third revelation focus is that the Muslims remain clear from interest for the sake of their own welfare. The fourth revelation makes the clear distinction between interest and trade; motivate Muslims to focus only on the principal amount and to relinquish this sum if the borrower has no capacity to repay. Further it is clear in the Holy book (Quran) that people are at war who disregard the prohibition of interest. The Holy Prophet Muhammad 
(S.A.W.W) said in his speech regarding interest: Allah has forbidden you to take interest; therefore, all interest obligations shall henceforth be forego. Your capital is yours to keep. You will neither inflict nor suffer any inequity. Allah has judged that there shall be no interest (Ahmad and Hassan,2010). Shariah regulates the Islamic banking and economic system, which firmly prohibits interest (riba) charges on loans (Roy, 1991). Under the Islamic laws Islamic banks are restricted to give and take interest (Aggarwal and Yousef, 2000). Shariah manages the Islamic banking; source of shariah is Quran and the Sunnah, according to the Islamic rules, interest based transactions are not allowed and it is the major characteristic of the Islamic banking. The primary sources of Shariah rules are the Quran, Sunnah, jurists and explainer of Islamic law (Blominvest Bank, 2009).

Islamic community plays a pivotal role over the effectiveness of an interest based banking system. While, it is clear that in the development of country banks play a major role as a financial intermediaries. Two fundamental Islamic rules of Islamic banking are the profit and loss sharing, notably, the restriction of the receiving and payment of interest. According to Islamic point of view, interest based financing is illegitimate (Anwar, 2003).

Finally, Muslim economists argue that the PLS system provides for cohesion between social classes because financing is equally available to anyone with a productive idea. With regard to the subject of stability, Muslim economists argue that an interest-based banking system fosters inflation, as the creation of money does not have any direct tie to whether or not a business venture is productive. The result is a higher cost to society for failed projects that interest was paid without any economic benefits.

\section{WHAT IS ISLAMIC BANK?}

Islamic bank is slightly different from the conventional banks because the Islamic banks shares profit and loss with its depositors but the conventional bank provides fixed rate of return on the investment deposited by the depositors. Profit and loss sharing is an agreement between the transacting parties to invest their pool resource in a project to share profit and loss. The Islamic economist argued that profit and loss sharing based on modes of financing which are named as Mudaraba and Musharaka, are used according to the Islamic perspective in which reward-sharing is related to the risksharing among the transacting parties. However, at present the almost theoretical models of Mudaraba or Musharaka or both, used by the Islamic banking are not matched with these models. Approximately all Islamic banks, investment companies, and investment funds offer trade and project finance on mark-up, commissioned manufacturing, or on leasing bases. PLS features marginally in the practice of Islamic banking and finance.
Islamic bank is an intermediary and trustee of other people's money like conventional banks with the difference that it shares profit and loss with its depositors. Profit and loss sharing difference introduces a mutuality concept in Islamic banking. Profit and loss sharing concept used by the Islamic banks according to the Islamic Shariah laws and according to this rule in Islamic banks, investment depositors are customers with some rights of ownership in the bank. On the other hand, most Islamic banks are operating and have an organizational set-up which is most similar to the conventional banks.

The main factor which contributes to the emergence of Islamic banking (PLS-banking system) is the prohibition of Interest (Riba) in the Holy Quran. The main reason to establish Islamic banking was the Muslims community desire to restructure their financial activities according to the Shariah principles (the Islamic Law) and make possible for them to accomplish their financial transaction without any involvement of Interest (Riba). In Shariah, the term Riba is used in two senses: 1) Is riba al-nasiah, advances fixing as a positive return on a loan as an incentive for waiting for repayment. 2) Is riba al-fadl, which represents the purchase of hand-to-hand and commodities sale. These both forms of riba are prohibited by the Shariah. According to riba al-nasiah, the reward on money with no measureable real economic increase is prohibited. On the other side, an increase in business activity resulting from the invested money riba is not considered by the Islamic community. It is very clear that the Islamic community appreciates the true profit.

As a return entrepreneurial benefits all of society and has no objection. Further, in the case of riba al-fadl, the Islamic community pays attention to ensuring justice and fair play in spot transactions to avoid any exploitation through unfair exchanges.

Bank Muamalat (BM), the first Islamic bank in Indonesia, is discussed as an example of how an Islamic bank is structured and operates in the market. Bank Muamalat (BM) was established as a private Islamic bank in Indonesia and started its operation on May 1, 1992 under the supervision of the government of Indonesia and Bank of Indonesia (Central bank). The board of commissioners (BOCs) substitutes the traditional role of BODs. Even though, the Shariah Supervisory Board has authority of decision making that rejects or sanctions any proposal in the light of Shariah (Islamic law). The supervisory board depends on the renowned religious scholars which BOCs appoint, are independent and have authority to reject any proposal viewed as against the Shariah principles.

Business operations management works under the Board of Directors (BODs), headed by a President Director who is directly responsible to BOCs, the Shariah Supervisory Board and Board of Auditors. Board of auditors responsible for the financial monitoring of the organization, which be composed of a group of auditors and one member of the auditors team must be member 
of the board of commissioners (BOCs) and also selected by the board of commissioners (BOCs).

However, the Islamic banks have started opening Profit and Loss Sharing (PLS) accounts. The profit and loss sharing accounts do not provide guarantee of fixed return on investment deposits because these accounts share the risk and reward on investment. This situation leads to unwillingness of the deposit holder of investment, who has no way to use the profit and loss sharing (PLS) and no representation in the organization. This problem is faced on the assets side by the bank in the similar way when it comes to investing on profit and loss sharing (PLS).

\section{HISTORY AND DEVELOPMENT OF ISLAMIC BANKING IN PAKISTAN}

The founder of Pakistan Quaid-e-Azam shows his interest for the development of interest free banking in the country, at the time when Quaid-e-Azam inaugurated the State bank of Pakistan. Initially the main purpose of many laws and principles is to remove the interest (Riba). Before 1970, Islamic banking was almost unknown, but in the start of twenty first century Islamic banking took place and became a reality. In 2004, the Islamic banking size touched the billion figures. The total accounts value of Shariah compliant worldwide is approximately USD 500billion and is growing with $10-15 \%$ (Zainol et al., 2008). According to economical and religious point of view, the interest free economic system is very crucial. In the 1970, the efforts were started for interest free banking system but the practical operation was started in the 1980s. Pakistan is one of those countries which started Islamic banking system at regional and national level (Roy, 1991). Islamic banking system was introduced in 19801s in Pakistan when State Bank of Pakistan make changes in rules and regulations of banking ordinance (Khattak and Rehman, 2010).

Pakistan put much more effort to implement interest free banking in the country and at that time Pakistan is considered as third country in the world who tries to implement interest free banking, (Banking Sector Review 2003 - 2007). However, many years passed to study this system; the Government of Pakistan appointed a council named as Council of Islamic Ideology (CII) to begin the implementation process of Islamic banking in February, 1979; and three credit institutions are shaped: Mutual Funds Investment Corporation of Pakistan, National Investment Trust and the House Building Corporation. The purpose is to remove interest based system immediately (Kennedy, 1990). NIT (National Investment Trust) and ICP (Investment Corporation of Pakistan) are two Government-owned mutual funds that started to eliminate interest from their financial operations by avoiding investing their funds in interest holding securities.
As a substitute a new system was introduce by the ICP in October 1, 1980, which was based on profit and loss sharing. The Islamic banking in Pakistan was a gradual process which started in February 1979. The implementation was a result of several years study and establishment of Islamic Ideology Council (IIC) by the Government of Pakistan.

The Investment Corporation of Pakistan main function was to push the private sector equity base, make efforts for the development of capital markets and changing the assets and liabilities into profit and loss sharing (PLS) modes in 1980. After this all the financial institutions focus on the mode of profit and loss sharing. The Council of Islamic Ideology (CII) did not suggest any changes in the system banking frame work, except the instructions once given through procedures. According to the plan the State Bank of Pakistan, Commercial banks and other specialized financial credit institutions would work under the existing rules and regulations, but the financial operation of these institutions would be on un-defined rate of return, instead of the fixed rare return based transactions (Interest based). The main purpose of that report was the implementation of Islamic financial system in different phases that will be focused by the some persons who make policies and the bankers towards complete Islamization (Khan and Mirakhor, 1990).

On January 1, 1981, all commercial banks of Pakistan separately interests free accounts had been opened and one foreign bank (Bank of Oman) had also considered this system and started operation to take deposit on the basis of profit and loss sharing (Banking Sector Review, 2003 - 2007).

At that time required changes were made in the concerned rules and laws empowering the State Bank of Pakistan to provide finance on participation term certificates. In addition, advances for support by Mudaraba Certificates, participation term certificates and promissory notes were increased from July 1,1982 , for the purpose to fulfill the working capital requirements of the industry and carefully operate the business. On the basis of Musharaka, bank can provide the finance on selective basis. In 1984, the banks were restricted to close the dual window functions by the Government and also instructed to terminate these functions in one year time period. On July, 1, 1985, the whole banking and financial system based on fixed rare return converted into Islamic Finance of which rate of return not fixed but can vary, but foreign currency deposits remain same to earn interest (Khan and Mirakhor, 1990).

In Pakistan, The premier Islamic Bank named Meezan bank introduced certificates and with the passage of time many Islamic banks entered. Six Islamic banks were operating at the end of 2007: Meezan Bank of Pakistan, Dawood Bank of Pakistan, Dubai Islamic Bank of Pakistan, Albarka Bank of Pakistan and the Global Emirate Bank of Pakistan (Khattak and Rehman, 2010). At present, the government of Pakistan has issued 
Table 1. Industry progress and market share.

\begin{tabular}{lllllllll}
\hline \multicolumn{9}{c}{ Rupees in billion and share and growth in percent } \\
\hline & Sept. 10 & Dec. 09 & Dec.08 & Dec.07 & Dec.06 & Dec.05 & Dec.04 & Dec.03 \\
\hline Total Assets & 424 & 366 & 276 & 206 & 119 & 71 & 44 & 13 \\
Share in Industry & 6.4 & 5.6 & 4.9 & 4 & 2.8 & 2 & 1.5 & 0.5 \\
Growth (YOY) & 31.2 & 32.7 & 34 & 73.1 & 65.3 & 63.6 & 238.5 & \\
Deposits & 338 & 283 & 202 & 147 & 84 & 50 & 30 & 8 \\
Share in Industry & 6.7 & 5.9 & 4.8 & 3.8 & 2.6 & 1.8 & 1.3 & 0.4 \\
Growth (YOY) & 38.2 & 39.9 & 37.4 & 75 & 68 & 66.7 & 275 & \\
Net Finance and Investment & 233 & 226 & 186 & 138 & 73 & 48 & 30 & 10 \\
Share in Industry & 4.6 & 4.5 & 4.3 & 3.5 & 2.3 & 1.7 & 1.3 & 0.5 \\
Growth (YOY) & 17.7 & 21.3 & 34.8 & 89 & 52.1 & 60 & 200 & 0 \\
Total Islamic banking Institutions & 19 & 19 & 18 & 18 & 16 & 11 & 11 & 4 \\
Total number of Branches* & 684 & 651 & 515 & 289 & 150 & 70 & 48 & 17 \\
\hline
\end{tabular}

Source: Annual Accounts except for September 2010, data which is based on Unaudited Quarterly Accounts. *number includes sub-branches.

licenses to six Islamic banks and 13 conventional banks to allow opening their Islamic banking branches for Islamic banking operations (Banking Sector Review, 2003 - 2007). In all over Pakistan, 6 full fledged Islamic Banks and 13 conventional banks started Islamic banking with more than 200 branches (Memon, 2007). In Pakistan, six full fledged Islamic banks are operating and 13 conventional banks are operating partially with Islamic window in different cities of Pakistan (Ahmed et al., 2010).

These banks are providing services in Pakistan and Islamic banks total assets were 225 billion as on June 2008 which cover the $4.5 \%$ market share of the all banking sector assets. Islamic banking covers the $4.2 \%$ market share of the total deposits of the banking sector. The branch network of Islamic banking is almost 330 branches in more than the 50 cities which cover the all four provinces of the Pakistan and also cover Azad Jammu Kashmir (AJK) (Banking Sector Review, 2003 2007).

Most essential part is to make the comparison between the Pakistan's Islamic banks progress and with the other countries of the world. The main purpose of progress comparison is to define the way for the Islamic banks of Pakistan. In Malaysia, Islamic banking starts its operation in 1983 and captures 13\% market share of banking sector of Malaysia but the given target by 2010 was $20 \%$ market share in the banking sector (Bank Negara Malaysia). Bahrain's Islamic banking system has obtained the $8 \%$ market share over the 30 years of working in the market. Similarly Islamic banking system of Indonesia was set up in the last century mid 90s (Bank Indonesia, 2007).
Pakistan's Islamic banks' performance is much better than the other countries' Islamic banks' performance. The industry progressed from 2003 - 2007 in terms of increase in branches, organizations, total financing, total deposits, total assets and investment. The Islamic banks total assets increased by 193 billion from 2003 - 2007. Year by year growth in the total assets is shown in the Table 1 (SBP, 2007).

\section{Growth of Islamic banking}

Islamic banking is established and growing at very rapid pace over the last two decades in the Muslim and nonMuslim countries as an alternative to the interest based banking system (conventional banking). First of all, Islamic bank was established by Egypt named as Mit Ghamr Saving Bank introduced by Egypt in 1963 and in the last four decades Islamic banking growth increased at very rapid pace in terms of size and in the numbers of players.

At present, Islamic banking is operating in more than 60 countries of the world and estimated growth rate is 15 - 20\% per annum. In Iran, Pakistan and Sudan, the entire banking system is converted into Islamic banking and also appreciated by these countries. In August 2004, first Non-muslin country issued license for Islamic banking to the Islamic Bank of Britain. The HSBC, the University bank in Ann Arbor and in Chicago Devon Bank introduced Islamic banking products in the United States. The size of Islamic banking is expected to reach an estimated USD 1,300 billion in the near future and 1100 Islamic financial institutions are offering their services 


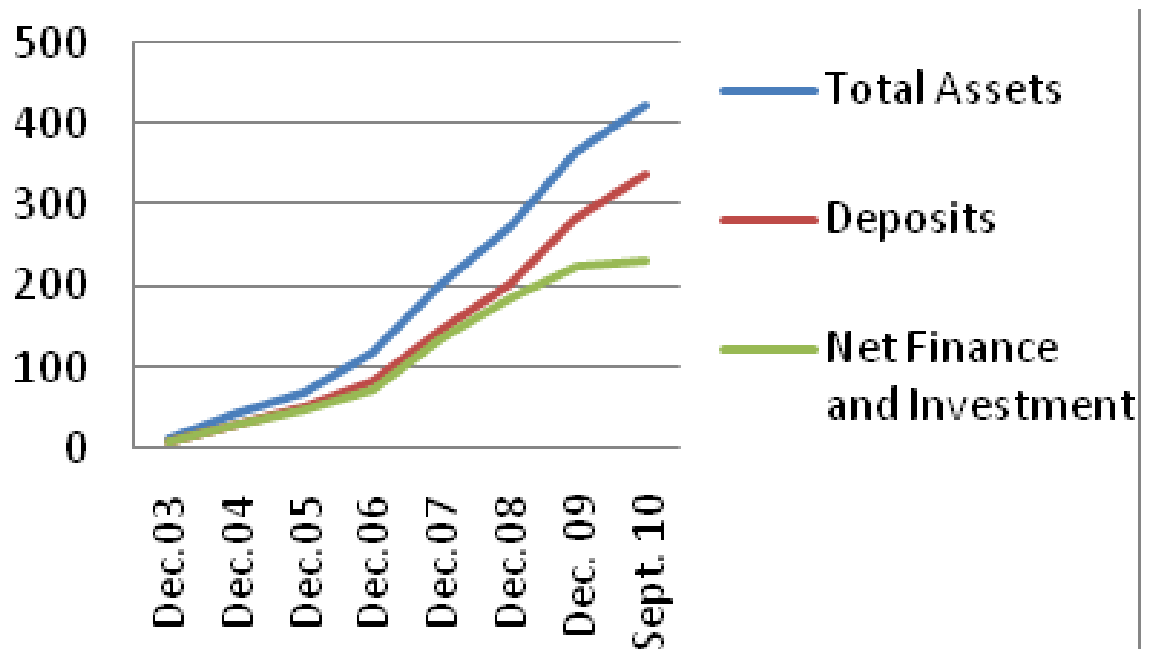

Figure 1. Share of Islamic Banking (\%).

around the globe. In the other countries of the world, the conventional banking system is still dominated and they are operating alongside Islamic banking. There is the trend of diversification toward the United State and Europe.

The fastest growing segment of credit market is Islamic banking in the Muslim countries. These banks market share has risen from $2 \%$ in the late 1970 s and risen about $15 \%$ in the mid 1990s as the bank assets measured (Babai, 1995). In this respect, Islamic financial instruments are also offered by the conventional banks. Islamic banking system is growing and becoming and becoming stronger and now is not a niche financial services industry. Finally, observations of many bankers are the system could be responsible for the management of over $50 \%$ of savings in the Islamic countries in the next decade.

\section{Growth of Islamic banking in Pakistan}

Islamic banking in the world wide has established itself and is growing at very fast pace. The Islamic banking size is expected to reach an estimated USD 1,300 billion in the near future. Presentably, across the globe 1100 Islamic financial institutions are offering their services, which are attached with devoted Islamic academic, legal, regulatory and supervisory institutions. This system provides a solid platform for future growth and development of the Islamic banking system.

In Pakistan, the State bank of Pakistan started Islamic banking system in 2000 and Islamic banking entrance creates a situation of high competition with the conventional banks which are already working in Pakistan. Islamic banks differ from the conventional banks with respect to products, operations and services.
Islamic banks did not offer predetermined rate of return on investment but based on the profit and loss sharing (PLS). However, first Islamic bank in Pakistan registered with the name of Meezan Bank of Pakistan in 2002 as full fledged first Islamic bank of Pakistan.

For Islamic banking, a complete set up for legal, regulatory and Shariah compliant framework was made before taking Islamic banking practical. The initiative in Pakistan was successful and has been a big success. Islamic banking industry has grown since the date of initiative and this time Islamic banking total asset has reached Rs 411 billion in June 2010. This shows an impressive growth on yearly basis of $31 \%$. The deposits growth of year on year basis has also been impressive $(39 \%)$ and the share of deposits and assets of Islamic banking have increased to 6.1 and $6.4 \%$ respectively. Although, the branch network of Islamic banking has increased to 667 branches and sub-branches spread across the entire country (Figure 1).

The growth of Islamic banking shows the overwhelming response from public is not only encouraging but also brings many opportunities for Islamic banking institutions which are commonly called IBIs. Islamic banking institutions have surplus of funds due to the continuous growth of deposits and they have the opportunity to focus on the areas which are un-served and under-served through diversifying their product mix (Anwar, 2010). State Bank of Pakistan Governor said that the bank is determined to ensure a level playing field for the Islamic banking industry. The state bank put a strong regulatory framework with a high focus on Shariah compliance and competitiveness. Anwar (2010) also added the bank plays a major role in the issuance of government of Pakistan ljara Sukuk, which has paved the way for effective liquidity management of Islamic banks. "We have also ensured a tax neutral regime for Islamic banking 
Table 2. Credit rating of banks and DFls updated as of May 01, 2010.

\begin{tabular}{|c|c|c|c|c|c|c|c|c|}
\hline $\begin{array}{l}\text { Serial } \\
\text { no }\end{array}$ & Name of banks & $\begin{array}{l}\text { Rating } \\
\text { agency }\end{array}$ & $\begin{array}{l}\text { Short } \\
\text { term }\end{array}$ & $\begin{array}{l}\text { Long } \\
\text { term }\end{array}$ & $\begin{array}{l}\text { Date of } \\
\text { rating }\end{array}$ & Remarks & & \\
\hline 1 & Al-Baraka Bank (Pakistan) Limited & PACRA & $A-2$ & $A$ & Dec, 2010 & & & \\
\hline 2 & Bank Islamic Pakistan Limited & & $\mathrm{A} 1$ & A & June, 2010 & & & \\
\hline 3 & Dawood Islamic Bank Limited & JCR-VIS & $A-2$ & A & April, 2011 & $\begin{array}{l}\text { Rating } \\
\text { stable }\end{array}$ & outlook & \\
\hline 4 & $\begin{array}{l}\text { Dubai Islamic Bank (Pakistan) } \\
\text { Limited }\end{array}$ & JCR-VIS & $A-1$ & $A$ & June, 2010 & $\begin{array}{l}\text { Rating } \\
\text { stable }\end{array}$ & outlook & - \\
\hline 5 & Meezan Ban k Limited & JCR-VIS & $A-1$ & AA & May, 2010 & $\begin{array}{l}\text { Rating } \\
\text { stable }\end{array}$ & outlook & \\
\hline
\end{tabular}

Source: State Bank of Pakistan.

transactions through amendments in tax laws" (Saleem, 2009) (Table 2).

\section{Market size and growth forecasts of Islamic banking}

Listed below assumptions have been made to forecast the market size and growth rates for Islamic Banking Market:

1.IBls will be able to channelize funds from huge untapped market

2.SBP will continue to play its supportive and dynamic role in providing suitable regulatory and Shariah compliance framework

3.IBls will be able to get their desired number of business places/branches

4.Shariah compliant Government liquidity instruments will be available in the market in these years.

5.Islamic Banking industry (IBIs and SBP) will be able to build, train or hire the necessary human resource base capable of catering to the requirement of attaining the outreach and market share envisioned by the industry (Table 3).

Moreover, based on the estimates up to the year 2012 received from major Islamic Banking Institutions, the forecasted size and expected growth rates of deposits and financing and also the human resource requirement of Islamic banking market in consolidated form are provided.

\section{Regulatory, supervisory and Shariah compliance developments}

At present, Islamic Banking launched again in Pakistan by the State Bank of Pakistan, that has been based not only due to the lessons learnt from the history of Islamic Banking efforts in Pakistan but also due the experience of other countries which are playing leadership role in this banking sector. State Bank of Pakistan's current policies and the previous efforts basic difference is the approach adopted by the State Bank of Pakistan in which the Islamic Banking Introduction can be viewed mostly as a change management rather than of religious or legal issue.

This basic approach difference defines the policies on Islamic banking and is mainly responsible for the achieved success so far. The decision was made to encourage the Islamic banking gradually and as a comparable and compatible system that in line of international patterns. The government statement is to convert the existing system into interest free system in different phases without causing any trouble. In addition, the approach also helps to build a large financial system in the country to enable the all population to access the financial services. State bank of Pakistan focused to provide the solutions to Islamic banking users which they require to maintain their financial relationship. The solutions provided by the State Bank of Pakistan are as practical and cost effective as provided by the conventional banking system however, these are Shariah compliant. The two key elements are in focus to ensure this.

Firstly, a sound regulatory framework, flexible, market driven and in line with international best practices.

Second a sound Shariah Compliance Mechanism, comprehensive, flexible, multi layered and acceptable locally and internationally.

\section{ROLE OF STATE BANK IN THE DEVELOPMENT OF ISLAMIC BANKING}

The role of lender of the last resort is not neglectable for the development of Islamic banking. The State Bank (Central Bank) of Pakistan is playing efficiently and effectively a significant role for the development of Islamic Banking in the country. To keep the banks in line for the development of the country, the State bank of Pakistan has established a separate a department for 
Table 3. Market size and growth forecasts of Islamic banking.

\begin{tabular}{|c|c|c|c|c|c|}
\hline $\begin{array}{l}\text { Deposits } \\
\text { (Rs. in millions) }\end{array}$ & 2008 & 2009 & 2010 & 2011 & 2012 \\
\hline $\begin{array}{l}\text { Total IB industry } \\
\text { deposits }\end{array}$ & 215,938 & 340,128 & 499,036 & 722,109 & 907,064 \\
\hline Annual growth rate & - & $58 \%$ & $47 \%$ & $45 \%$ & $26 \%$ \\
\hline $\begin{array}{l}\text { Financing } \\
\text { (Rs. in Millions) }\end{array}$ & 2008 & 2009 & 2010 & 2011 & 2012 \\
\hline $\begin{array}{l}\text { Total IB industry } \\
\text { financing }\end{array}$ & 184,641 & 277,153 & 413,594 & 600,014 & 731,591 \\
\hline Annual growth rate & - & $50 \%$ & $49 \%$ & $45 \%$ & $22 \%$ \\
\hline $\begin{array}{l}\text { Human resource } \\
\text { requirement }\end{array}$ & 2008 & 2009 & 2010 & 2011 & 2012 \\
\hline Total IB Industry HR & 9,601 & 13,063 & 16,181 & 19,220 & 20,953 \\
\hline Annual growth rate & - & $36 \%$ & $24 \%$ & $19 \%$ & $9 \%$ \\
\hline
\end{tabular}

Islamic banks named Islamic Banking Department. The main objective of this department is to enable the Islamic banking that the users and the suppliers assign a priority as the $1^{\text {st }}$ choice banking. To develop the Islamic banking system, the very important is transparency of Shariah compliance with respect to the international practices of state bank of Pakistan. To convert the interest based financial system into interest free financial system, the effort has been made since 1979. Primarily, 12 modes of Islamic financing introduced by the lender of last resort (SBP) to replace the interest based financial system. In 1980, the Islamic Ideology Council advised the State Bank of Pakistan to make change in the discount rate in money market by introducing the system of profit and loss sharing (Memon, 2007). In 1980, the State Bank of Pakistan took initiate for Islamic banking implementation and made changes in the rules and regulations in Banking Ordinance. After adopting the profit and loss sharing system, every commercial bank on $1^{\text {st }}$ July 1985 became interest free (Khattak and Rehman, 2010).

In 2000, the State Bank started Islamic banking system and Meezan Bank of Pakistan registered in 2002 as full fledged first Islamic bank of Pakistan. The entrance of Islamic financial system in Pakistan created a situation of high competition with the existing conventional banks as there is a difference of operations, services and products, (Ahmed et al., 2010).

On the 15th September, 2003, the Islamic Banking Department shaped with the objective to develop and promote the Shariah compliant banking as a compatible banking system in the region. In the worldwide financial market Islamic banking is at growing with wonderful potential and globally growing at very fast pace. By the grace of Allah, in Pakistan Islamic banking is at progress and growing very fast from the several years. At present, in Pakistan 6 full fledged licensed Islamic banks are working and 12 conventional banks operating with
Islamic banking windows.

Due to increasing market share of Islamic banking, some other banks have also sent their requests which are in consideration. State Bank of Pakistan first preference is to promote full-fledged Islamic banking. Interest-free liquidity management most of the time is requirement of Islamic banking. Cash reserve requirement (CRR) five per cent and statutory liquidity requirement is eight per cent for both Islamic banks and conventional banks by the State Bank of Pakistan (SBP) (Memon, 2007).

The mission statement of State Bank of Pakistan is to develop a sound Islamic banking system that is aligned and compatible with the worldwide financial sector that should provide unique Shariah compliant products and services to its clients in order to achieve equitable economic growth in Pakistan, (State Bank of Pakistan).

\section{CONCLUSION AND RECOMMENDATIONS}

Islamic banks operate under the Shariah principles (Islamic Law) and that is why Islamic banking is also appreciated by the Muslim countries. The main reason behind the appreciation of Islamic banking is the prohibition of Interest in the financial transactions.

In Pakistan, the growth rate of Islamic banking is at very fast pace as compared to the other countries of the world. Fast growth and development's reason of Islamic banking is the role of central bank of Pakistan. State Bank of Pakistan established a separate Islamic Banking Department to support the Islamic banking to make it as the first choice of the banking.

Due to this support Islamic banks captured the reasonable market share such as at present the Islamic banking has reached total assets worth Rs 411 billion in June 2010, showing an impressive year on year growth 
of $31 \%$. The year on year deposits growth has also been impressive $39 \%$ and the share of assets and deposits of Islamic banking have increased to 6.1 and $6.4 \%$ respectively. While Islamic banking branch network has increased to 667 branches and sub-branches spread across the entire country. Islamic banks credit ratings are normally satisfactory and are performing their operations successfully.

Growth of Islamic banking in the Pakistan shows that people are interested and satisfied with Islamic banking operations. Islamic banks based on the profit and loss sharing (PLS) in which the investor share the risk and reward, no predetermined return provided on the investment. At present, six full fledged Islamic banks are operating and 12 conventional banks are operating with Islamic window in Pakistan.

Islamic banking is still a new concept and people are unaware of it and its operations. To create the awareness of Islamic banking there is a need to create awareness and educate the people about its functions such as investment on profit and loss sharing (PLS). Islamic banks works according to the Shariah principles (Islamic law) so there is need to train the human resource according to the Shariah principles (Islamic law).

To develop the Islamic banking system, the very importance is transparency of Shariah compliance with respect to the international practices of state bank of Pakistan. To convert the interest based financial system into interest free financial system, a lot of efforts has been made. To increase growth and capture the market share Islamic banks should extend interest free financial services towards low income community. The regulatory bodies make the rules and regulations for Islamic banking system and have a management control over the implementations of corporate governance in interest free banking system. Introduction of liquidity management and monitory policy is the key part for the promotion of Islamic banking. Islamic banking must introduce new products and innovative services to capture the market share and for long run existence.

\section{REFERENCES}

Aggarwal RK, Yousef T (2000), Banks and Investment Financing: J. Money, Credit and Banking. 32(1): 93-120.

Ahmad A, Kashif-Ur-Rehman, lqbal SM (2010). Islamic Banking Experience of Pakistan: Comparison between Islamic and Conventional Banks. Int. J. Business and Management. 5 (2).

Babai D (1995). Arab Banker's Association of North America Newsletter.

Central bank of Indonesia.Available at: http://www.bi.go.id/web/en

Council of Ideology.Available at:http://www.cii.gov.pk/

http://www.sbp.org.pk/ibd/bulletin/2010/IBB-Sep-2010.pdf

http://www.sbp.org.pk/ibd/bulletin/bulletin.asp

http://www.sbp.org.pk/ibd//slamic-Bkg-Review-03-07.pdf

http://www.sbp.org.pk/press/2009/Dubai-Islamic-25-Nov-09.pdf

Islamic banking bulletin, vol-4\&10, (2006-2010). Available at:

Kennedy $\mathrm{CH}$ (1990). Islamization and legal reforms in Pakistan. Pacific affairs, 36(1), 62-77.

Khan SM, Mirakhor A (1990). Islamic Banking Experiences in the Islamic Republic of Iran and in Pakistan. Economic Development and Culture change.38 (2), 353-375

Khattak AN, Kashif UR (2010). Customer satisfaction and awareness of Islamic banking system in Pakistan. Afr. J. Business Management, Vol. 4(5): 662-671.

Memon NA (2007). Islamic Banking: Present and Future Challenges. J. Management and Social Sciences, Vol. 3(1): 01-10.

Richard DB, Ruder C (1999). "Middle East: An overview of project finance and Islamic finance". Int. Financial Law Review London. 4044.

Roy AD (1991). Islamic Banking, Middle Eastern study, 27(3), 427-456

Saleem R (2009). Available at:

SBP-Banking sector review.Available at:

Yaseen A( 2010).Available at:

Zainol Z, Shaari R, Ali HM (2008), A comparative analysis of bankers perceptions on Islamic banking, Int. J. Business and management. 3(4): 157-168. 